\title{
The Good Food Revolution:
}

\section{Growing Healthy Food, People, and Communities.}

by Will Allen

Published by Penguin, 2012, 272 pages

Reviewed by

Nick Smith (NicholasSmith@ferris.edu), Ferris State University

The Good Food Revolution by Will Allen is a great read for first-year college students. Will Allen has followed many career paths through his life, but he has always remained a farmer at heart. He grew up the son of a sharecropper and learned early on about hard work. Allen has spent time as a college and professional basketball player, working in retail and merchandising, and eventually returning to farming . . . but this time, in an urban setting.

His parents were actually part of the "Great Migration," in which many African Americans left the rural South to more urban areas of the northern states. Once they found a new home in the north, they continued to farm vegetables and raise chickens for food. Allen's parents worked a variety of jobs to provide for the family, but also sold some of their extra crops to make ends meet. They also lived off whatever animals wandered onto their farmland, such as squirrels, rabbits, groundhogs, and even snapping turtles.

During this time, Allen went through a bit of a growth spurt. He was already 6 feet tall when entering the seventh grade. This was also the time he first discovered his love for the game of basketball. His brother had gotten an old basketball rim from a friend and nailed it up on an oak tree by a flat area on their land. Allen could dunk at the age of twelve and was so passionate about the game that he was known to sleep with a basketball under his arm. This dedication and skill would lead him to a path out of farming, or so he thought. This text could be used to get first-year students to think about goals and dedication as they pursue their education.

Allen became a well-recognized high school basketball player. He received many scholarship offers from colleges to play basketball. He went on to play college basketball and never expected to return to farming. He eventually chose the University of Miami and became one of the first African Americans in the school's integrated athletic programs. This could be used to discuss topics of going away to college and being immersed in a new environment.

He faced discrimination and other hardships and often just the unknown, as 
Florida was far from his home in Maryland. Allen was the first African American basketball player at the University of Miami, and there was one other African America athlete that was on the football team. They both dealt with forms discrimination and threats upon their arrival at school. Allen received threatening racist letters as well as other forms of harassment during his time in college.

Allen also fell in love very quickly upon entering college, where he met an upperclassman named Cyndy Bussler. They began dating and fairly quickly married. He was only 20 years old, and Bussler was only 23 . The marriage was controversial, not only because of the shortness of the courtship, but because Bussler was White and Allen was Black. This was not an extremely common scenario in the late 60s. Their parents, especially Bussler's, did not approve. Diversity and inclusion could also be discussed, based on this time in Allen's educational pursuits.

While in school, there was a chance that the basketball program would be cut during his senior year. The school held off but decided to disband a year later, which at least provided Allen the opportunity to finish college. After graduation, he never played in the National Basketball Association, but he did play briefly in the American Basketball Association. Allen was not very successful in his professional basketball career in America, which led him to play in Europe.

He was offered an opportunity by a team in Belgium. He discussed the situation with his wife. They had two young children at this point, but she agreed so he could continue to follow his career path of playing basketball. While playing basketball in Europe, he ended up assisting with a farm, which brought many childhood memories a back to him. This could, of course, also be used in a lesson about experiencing different cultures and learning new things. He enjoyed his time in Europe, but playing on concrete courts was taxing on his body, so he knew his time there would be limited.

He returned to the United States and had management jobs with Kentucky Fried Chicken and Proctor and Gamble, but he continued to farm while working. He moved to Milwaukee, where his wife was originally from, and purchased a failing plant nursery. He took a big risk purchasing a farm in Milwaukee, which had become a much more industrial than rural area, but farming was now a passion of his, so he felt the dangers were worth it. While this endeavor was a big risk, which included many long hours and financial hardships, he was able to be his own boss, which is something he learned he desired during his corporate jobs. This could lead into a great discussion about finding the correct career path.

Allen networks with other farmers, local government officials, and general members of the community. He participates in a local farmers market, where he is not accepted immediately, as he is the new person in a very established community culture. He helps a few community organizations to improve the urban area. They provide hands-on farming experience to the local urban youth, which they generally would not receive in a metropolitan area. Students could analyze this to discuss communication skills and even networking opportunities.

Between some of the chapters of the book, there are also excerpts on getting 
started with a project and having patience with the process. Allen even gives some details on how to start composting and to build a simple greenhouse. The book describes food deserts and access to health foods in urban and poorer neighborhoods. Discussion on these topics, or socioeconomic status in general, could be very educational for first-year students.

Throughout the book, there is a subplot about Karen Parker and her family. Parker had worked for Allen at Kentucky Fried Chicken, then again, assisting him with stocking shelves when he worked in merchandising for Proctor and Gamble. When Allen realized that he needed a manager for his greenhouse and roadside market, he talked to Parker about the opportunity for her and her family.

Allen rented Parker a house and hired her to assist in running his greenhouse and market. Parker faced many hardships, including being abused, financial struggles, and being a single parent. Her son, DeShawn, was severely burned at a very young age, which left him with many visible scars and self-conscience of his appearance. DeShawn ends up spending quite bit of time at the greenhouse; he doesn't say much, but he does help Allen and learn some farming skills. DeShawn also comes out of the closet at a young age, which his family easily accepts.

Between his physical scars and being a gay African American male, he understands being different and discovers his own identity. Eventually, he determines his career path and pursues a degree in culinary arts. This section of the book could be used as a topic for an assignment on self-reflection and finding the appropriate career path.

The market struggled very much in the beginning, even with the assistance of Parker and her children. Allen took out numerous loans and worked excessive hours trying to operate his own business. Parker even wrote personal checks to pay utilities to operate the greenhouse, even though she did not have the money in her account to cover the checks.

Allen starts developing his own fertilizer through composting and worm farms. He is even able to sell his fertilizer to generate a small amount of extra income. He also learns to make self-sustaining greenhouses with fish farms that help generate heat and create more nutrient-rich fertilizer. This innovation could be used to discuss creativity and critical thinking skills.

Eventually, all of Allen's greenhouse activities attract some attention. He is visited by Hope Finkelstein, who has established a community farming program called "Growing Power." The organization provides internship opportunities for local students as well as mentorship programs to provide alternative activities for the community. Allen agrees to become a board member of the organization. The organization gathers people from many different cultures to work together in their farming efforts. This program brings even more attention to Allen.

Allen received the MacArthur Genius Grant for his strides to bring attention to and improve urban farming. This is an extremely prestigious award, as he receives an unrestricted $\$ 500,000$ grant over the course of five years. This, of course, gave him some well-earned publicity and the opportunity to tell his story through this book. He continues with his programs and has even become a speaker on numerous talk shows and college campuses across the country. 
Overall, the book could be used well as a common read for first-year students. While it does weave in and out of a few different but related stories, the book remains interesting by not telling a simple linear story. The book touches on a variety of interesting and current topics that could be relevant to many college students. Allen gives solutions to food deserts, urban blight, and even overcoming adversity. More importantly, he gives examples of diversity, perseverance, motivation, and finding the correct career path, all of which are important topics for first-year college students. 